\title{
Mercury distribution in the main compartments of the eutrophic Lake Candia (Northern Italy)
}

\author{
Maria Chiara FONTANELLA, Oscar RAVERA*, Gian Maria BEONE ${ }^{1)}$, Nicoletta RICCARDI and Ilenia CATTANI ${ }^{1)}$ \\ CNR - Institute of Ecosystem Study, Largo Tonolli 50, I - 28922 Verbania Pallanza, Italy \\ ${ }^{1)}$ Università Cattolica del Sacro Cuore, Istituto di Chimica Agraria e Ambientale, Via E. Parmense 84, 29100 Piacenza, Italy \\ *e-mail corresponding author: oscar.ravera@ise.cnr.it
}

\begin{abstract}
Total mercury (T-Hg) and organic mercury (mainly methylmercury, MeHg) concentrations in the most important compartments (water, sediment, macrophytes, zooplankton, mussels and fish) of the shallow and eutrophic Lake Candia (Turin, Northern Italy) were measured. The decreasing sequence of the T-Hg concentrations is as follows: cat-fish (143 $\mu \mathrm{g} \mathrm{kg}{ }^{-1}$ d.w.), zooplankton (77 $\mu \mathrm{g}$ $\mathrm{kg}^{-1}$ d.w.), Unio pictorum mancus (37.9 $\mu \mathrm{g} \mathrm{kg}^{-1}$ d.w.), macrophytes $\left(28.9 \mu \mathrm{g} \mathrm{kg^{-1 }}\right.$ d.w.). The content of mercury in mussel tissues increased with the size of the animal, but the relationship between $\mathrm{Hg}$ concentration and tissue weight was negative, indicating that the rate of mercury accumulation was lower than the tissue growth rate. The amount of mercury accumulated in the mussels living in the lake sediments was estimated to be $0.54 \mu \mathrm{g} \mathrm{m}^{-2}$. The importance of mercury biomagnification is also discussed.
\end{abstract}

Key words: fish, mollusc, macrophytes, zooplankton, mercury, biomagnification

\section{INTRODUCTION}

Interest in mercury contamination focuses primarily on its organic compounds, particularly methylmercury (MeHg), due to its high toxicity. A diet based on fish highly contaminated by mercury discharged with industrial effluents caused the poisoning of fishermen and cats in Minamata Bay (Japan) and attracted attention to a serious mercury-induced neurological and cardiovascular diseases (Sorensen et al. 1990). Since then mercury and its compounds have been regarded by national and international norms (e.g., WHO-IPCS 1990) as the most toxic of heavy metals. The organic forms (e.g., dimethylmercury) are more volatile, more toxic, and more readily available to organisms than the inorganic compounds, and have a different distribution in the environment.

When mercury and its inorganic species are transferred from point sources (ores, rocks, effluents) or diffused sources (atmosphere) to a water body, they may be transformed into organo-metals (e.g., monomethylmercury, dimethylmercury) by bacterial and algal activity (Jensen \& Jernelov 1969; Jernelov \& Lann 1971; Mason et al. 1996). In fresh and brackish waters the sulphate-reducing bacteria are the most efficient microrganisms in the methylation process, which mainly occurs at the sediment-water interface and, to a lesser extent, in the water column. The opposite process, demethylation, is also mainly due to bacterial activity at the sediment surface. Therefore, the MeHg concentration in the aquatic environment is the result of the balance between the methylation and the demethylation processes (Campeau \& Bartha 1984).
Experimental studies have focused on the relationships between the two processes (e.g., Rambal et al. 1986; Hintelman \& Evans 1997) and on the influence of biotic and abiotic factors. For instance, Gardfeldt et al. (2003) demonstrated that methylation is substantially driven by biotic factors, while it is poorly affected by abiotic conditions. A relatively important role has been attributed to solar radiation, which seems to be involved in both the formation and decomposition of MeHg. The influence of light is obviously limited to the photic layer, where the highest photosynthetic activity is sustained by phytoplankton. The release of soluble extracellular organic substances (e.g., glycine) by planktonic algae stimulates the bacterial activity, thus indirectly contributing to the production and decomposition of MeHg.

Aquatic animals take up $\mathrm{MeHg}$ from both water and food, but generally food seems to be the most important source of MeHg for zooplankton (Tsui \& Wang 2004) and fish (Hall et al. 1997). The ability of organisms to survive in environments heavily polluted by toxic metals (e.g., mercury) varies with the species. The capacity of some species for accumulating in their bodies metal concentrations exceeding their physiological needs by 2 or 3 orders of magnitude without evident damage justifies the use of some of these species as bioindicators of accumulation for one or more pollutants. One of the commonly used bioindicators for mercury is fish, with muscle the tissue analysed, even though the highest mercury concentration occurs in liver and kidney (Jernelov \& Lann 1971). However, muscle has some important advantages; for example, most of the fish's weight derives from muscle, which may be easily isolated from other tissues, the organic mercury percentage 
in the muscle is fairly high, and it is an important food for several species, including man.

The study of mercury distribution, and particularly that of its organic forms, is not only justified by its high toxicity and its persistence in the environment, but also to the fact that it is easily and readily available to animals and has a tendency to increase its concentration along the trophic chain (biomagnification).

Continuous progress in analytical chemistry means that researchers are now able to tackle the problems of the biogeochemical cycle of mercury and its physical and chemical forms.

The main objective of this research was to assess the concentration and distribution of total mercury $(\mathrm{T}-\mathrm{Hg})$ and its organic forms $(\mathrm{MeHg})$ in the major compartments (water, sediment, macrophytes, zooplankton, bivalve and fish) of a shallow and eutrophic lake (Lake Candia, Turin, Northern Italy). This lake is characterized by low toxic metal concentrations and receives mercury only from atmospheric depositions.

\section{MATERIALS AND METHODS}

\subsection{Study site}

The research was carried out in Lake Candia (Northern Italy, latitude N 4519'32"; longitude E $\left.7^{\circ} 54^{\prime} 38^{\prime \prime}\right)$. The most important morphometric characteristics are reported in table 1. Further details on this shallow and eutrophic lake may be found in Ravera et al. (2007a).

\subsection{Sampling and sample preparation}

Macrophytes (Trapa natans, Myriophyllum spicatum, Nymphoides peltata) and mussels (Unio pictorum mancus) were collected at random by hand. The mean value of the mussel shell length was $78 \mathrm{~mm}(49 \div 95$ $\mathrm{mm}$ ). The young of the year (YOY) fish (Ictalurus melas) of $4-5 \mathrm{~cm}$ length were captured with a nylon net and the plankton with a conical net (mesh size $=85 \mu \mathrm{m}$ ).

Tab. 1. Morphometric characteristics of Lake Candia (Giussani \& Galanti 1992).

\begin{tabular}{lc}
\hline Altitude $(\mathrm{m}$ a.s.l.) & 226 \\
Watershed area $\left(\mathrm{km}^{2}\right)$ & 9.9 \\
Lake area $\left(\mathrm{km}^{2}\right)$ & 1.5 \\
Mean depth $(\mathrm{m})$ & 3.8 \\
Maximum depth $(\mathrm{m})$ & 7.7 \\
\hline
\end{tabular}

The plankton sample was divided into two sub-samples: a small one was preserved in a 5\% neutralized formaldehyde solution and subsequently used for microscopical analyses; a larger sample was used for chemical analyses. The plankton sample was almost exclusively made up of Crustaceans (Cladocera and Copepoda); Chaoborus flavicans larvae and Rotifers (Asplanchna priodonta) were present in a very low density. Phytoplankton consisted of only a few small colonies of Microcystis sp. (Tab. 2). Due to the small size of the young cat-fish (Ictalurus melas), the entire body was analyzed.

Surface water samples were filtered (Millipore 0.45 $\mu \mathrm{m})$ soon after collection and preserved in plastic bottles. Surface sediment was collected using a plexiglass core sampler (inner diameter $=7 \mathrm{~cm}$ ).

All the samples were preserved in plastic bags placed in an ice-box and brought to the laboratory, where they were kept at $-20^{\circ} \mathrm{C}$ until the chemical analyses were performed, within 20-25 days after sample collection.

Tab. 2. The most abundant species of zooplankton in Lake Candia sample.

\begin{tabular}{l}
\hline Cladocerans \\
Ceriodaphnia quadrangula \\
Ceriodaphnia pulchella \\
Daphnia hyalina-galeata-cucullata complex \\
Diaphanosoma brachyurum \\
Eubosmina coregoni \\
Copepods \\
Eudiaptomus gracilis \\
Mesocyclops leuckarti \\
Thermocyclops crassus \\
\hline
\end{tabular}

\subsection{Chemical analyses}

Total mercury (T-Hg) was measured by using solid/liquid atomic absorption spectrometer $\mathrm{Hg}$ analyser (Advanced Mercury Analyzer, AMA 254 model, FKV) based on combustion of the sample in oxygen atmosphere and amalgamation preconcentration on a single gold trap. Precision and accuracy were checked using standard reference materials (mussel tissue BCR 278 and estuarine sediment ERM 580) and replicate analysis. The quality control gave good precision $(\mathrm{SD}<5 \%$ ) for almost all samples.

The organic species of mercury (ethylmercury and methylmercury) were determined by HPLC-ICP-MS (HPLC 1100 Agilent model coupled with an ICP-MS 7500 ce Agilent model) following the procedure described by Cattani et al. (2008). The only organic form found in the samples was methylmercury $(\mathrm{MeHg})$. The water samples were injected directly into HPLCICP-MS. The extraction from $1 \mathrm{~g}$ of lyophilized solid samples was obtained with the addition of $9 \mathrm{~mL} \mathrm{HCl}$ $(7.6 \% \mathrm{w} / \mathrm{v})$ and $1 \mathrm{~mL}$ mercaptoethanol $(10 \% \mathrm{w} / \mathrm{v})$. The mixture was placed for 45 minutes in ultrasonic bath with ice in the water to prevent excessive warming. An aliquot of clear solution was brought to $\mathrm{pH} 6.8$ with ammonia $(10 \% \mathrm{w} / \mathrm{v})$. After being diluted ten times with deionized water (18 M $\Omega$-cm resistance, Millipore ${ }^{\circledR}$ system), the sample solutions were filtered through a 0.45 $\mu \mathrm{m}$ membrane before HPLC-ICP-MS analysis. The $\mathrm{m} / \mathrm{z}$ signal adopted was 202. More details of working parameters of the instruments are reported in Cattani et al. (2008). The extractions and HPLC-ICP-MS measurements were made on the same day. Spike addition, replicate determinations and analysis of certified standard 


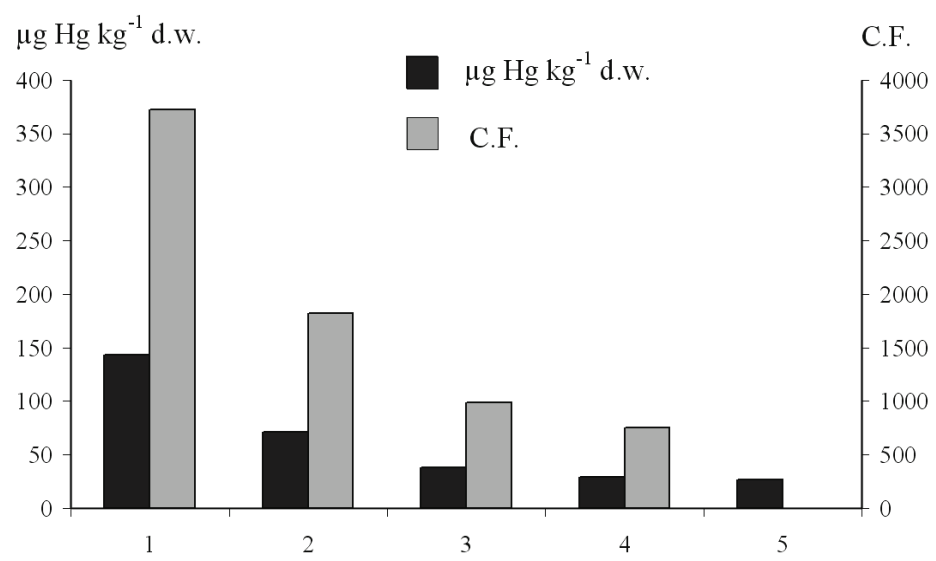

Fig. 1. Concentrations of mercury ( $\mu \mathrm{g} \mathrm{kg}{ }^{-1}$ d.w.) and concentration factors (C.F.) in the most important compartments of Lake Candia. 1) fish, 2) zooplankton, 3) mussel, 4) macrophytes, 5) sediments

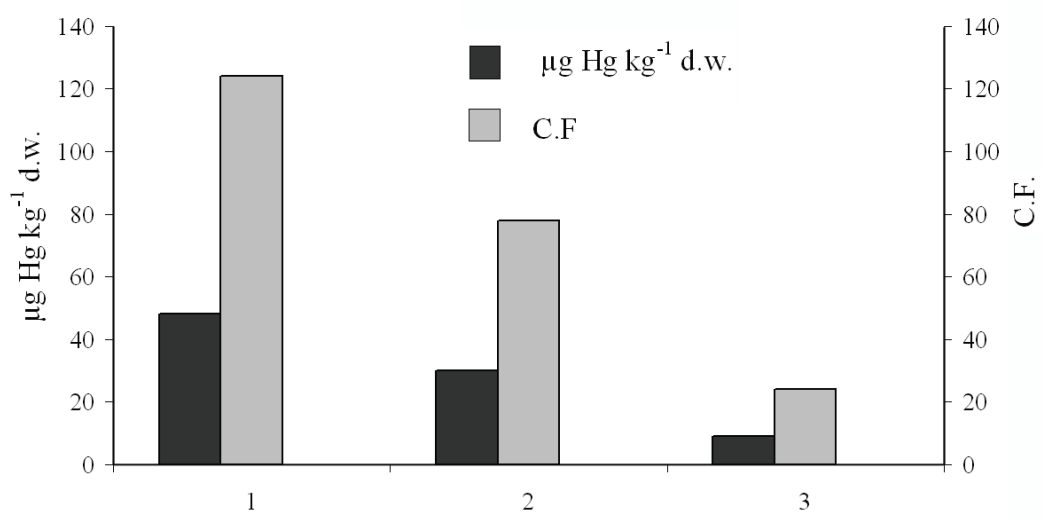

Fig. 2. Concentrations of mercury ( $\mu \mathrm{g} \mathrm{kg}^{-1}$ d.w.) and concentration factors (C.F.) in macrophytes 1) Trapa natans, 2) Myriophyllum spicatum, 3) Nymphoides peltata.

ERM 580, estuarine sediment certified for the $\mathrm{MeHg}$ and $\mathrm{T}-\mathrm{Hg}$ concentration, were carried out to verify the precision and accuracy of the measurements.

\subsection{Calculations}

The concentration factor (C.F.) was calculated as the ratio between the concentration of the $\mathrm{T}-\mathrm{Hg}$ in the organism (related to wet weight) and its concentration in the filtered water.

Spearman's coefficient of rank correlation was calculated to measure the intensity of association observed between the concentration of mercury in the mussel tissues, and the mussel size. Non-parametric correlation analysis was used, since the data were not normally distributed as verified by a normality test according to the Kolmogoroff-Smirnoff method.

\section{RESULTS}

The T-Hg and MeHg concentrations in the most important compartments of Lake Candia and the concentration factor (C.F.) values are reported in figure 1.
Since the $\mathrm{T}-\mathrm{Hg}$ concentration in the filtered water $\left(0.005 \mu \mathrm{g} \mathrm{L}^{-1}\right)$ is the same, the C.F. values for all the compartments analyzed are proportional to the $\mathrm{T}-\mathrm{Hg}$ concentrations in each of them.

The decreasing sequence of the $\mathrm{T}-\mathrm{Hg}$ concentrations is the following: Ictalurus melas $>$ zooplankton $>$ Unio pictorum mancus (bivalve) $>$ macrophytes $>$ sediments $>$ filtered water. The $\mathrm{MeHg}$ percentage of the $\mathrm{T}-\mathrm{Hg}$ is $13 \%$ in the zooplankton but decreases to $2.8 \%$ in the macrophytes, which is a value of the same order of magnitude as that measured in the sediments: $3.3 \%$ in the first $\mathrm{cm}$ and $3.7 \%$ in the second centimetre.

The mean concentration of $\mathrm{T}-\mathrm{Hg}$ in the macrophytes was fairly low (Fig. 2), but the differences between species were quite wide and decreased from Trapa natans $\left(47.6 \mu \mathrm{g} \mathrm{kg}^{-1} \mathrm{dw}\right)$ to Myriophyllum spicatum $(30.0 \mu \mathrm{g}$ $\left.\mathrm{kg}^{-1} \mathrm{dw}\right)$ and Nymphoides peltata $\left(9.12 \mu \mathrm{g} \mathrm{kg}^{-1} \mathrm{dw}\right)$. The $\mathrm{MeHg}$ concentrations were $1.67 \mu \mathrm{g} \mathrm{kg}^{-1} \mathrm{dw}$ in Trapa natans and $0.40 \mu \mathrm{g} \mathrm{kg}^{-1} \mathrm{dw}$ in the other two species.

The content of mercury in mussel tissues increased with animal dry weight, but a tendency towards a decrease of mercury concentration in the tissues with 

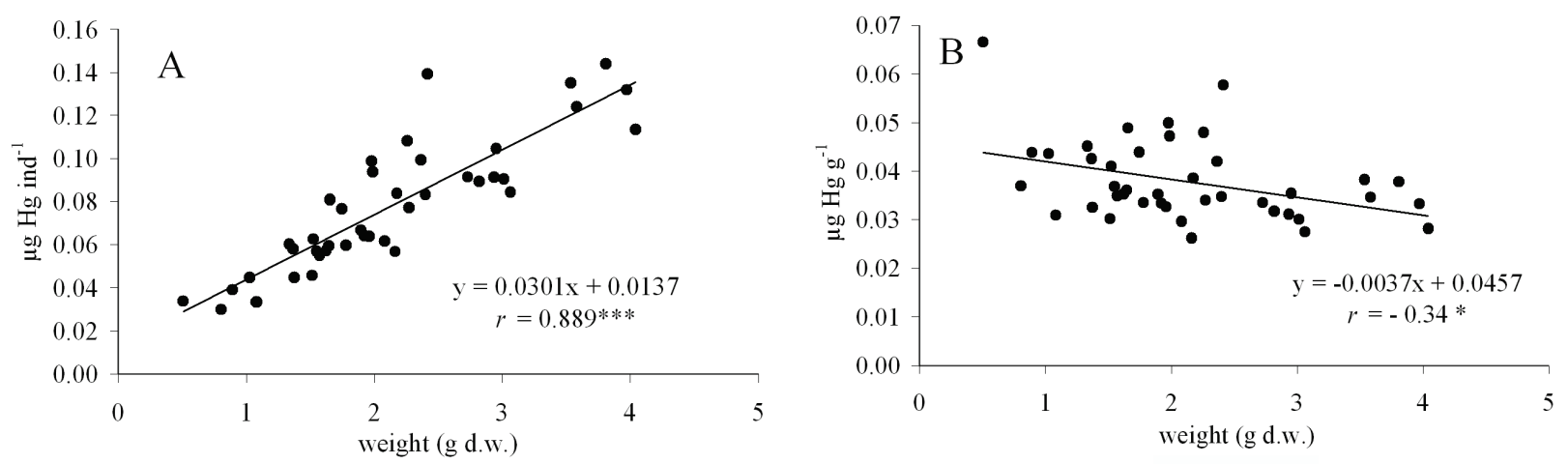

Fig. 3. Relationship between Unio soft tissue weight and mercury content in the mean individual mussel (A) and between soft tissue weight and mercury concentration in mussel tissues (B). $*=p<0.05 ; * * *=p<0.001$.

the increase in tissue weight was quite evident, even though the relationship was not statistically significant (Fig. 3).

\section{DISCUSSION}

Mercury concentration in aquatic organisms is the combined result of several variables, such as the concentration of the available forms in the water and food, the age and size of the organism and its place in the food-web.

\subsection{Fish}

Because of the high mercury concentration in fish and the large percentage of its organic forms, which are also more toxic, fish are excellent indicators for estimating the mercury contamination level of the environment. In fact, the T-Hg concentration in Ictalurus melas from Lake Candia (143 $\mu \mathrm{g} \mathrm{kg}^{-1}$ d.w.) was about twice that measured in net plankton $\left(77 \mu \mathrm{g} \mathrm{kg}^{-1}\right)$ and about five times higher than the mean concentration in the macrophytes $\left(28.9 \mu \mathrm{g} \mathrm{kg}^{-1}\right)$. Ulbrich et al. (2007) analyzed the T-Hg in fish species from various water bodies from Kazakhstan, finding the highest values and the widest variability in Perca fluviatilis $(190 \div 1680 \mu \mathrm{g}$ $\left.\mathrm{kg}^{-1}\right)$ and Tinca tinca $\left(160 \div 1120 \mu \mathrm{g} \mathrm{kg}^{-1}\right)$; Grieb et al. (1990) measured concentrations from 40 to $360 \mu \mathrm{g} \mathrm{kg}^{-1}$ in Perca fluviatilis from various water bodies in Michigan.

The major drawback of using fish as indicators regards their mobility and the migratory behaviour of some species; this can make it difficult to establish whether all the mercury measured in the fish was accumulated in the habitat from which it was captured. In our case, a very low mobility can be reasonably assumed, since YOY cat fish live in swarms which explore a limited littoral area.

\subsection{Zooplankton}

Due to their short life-span and rapid rates of metal uptake and loss, zooplankters are very useful indicators of the present mercury pollution level (Tsui \& Wang 2004). The specific composition and the size structure of zooplankton varies widely not only with the environment but also with the season; as a consequence, wide variations over time of $\mathrm{T}-\mathrm{Hg}$ and $\mathrm{MeHg}$ concentrations may be expected, even if the mercury concentration in the water is constant. The samples from lake Candia were essentially composed of crustaceans (Tab. 2), with $\mathrm{T}-\mathrm{Hg}$ and $\mathrm{MeHg}$ concentrations $\left(77 \mu \mathrm{g} \mathrm{kg}^{-1}\right.$ and $9.32 \mu \mathrm{g} \mathrm{kg}^{-1}$ ) falling in the very wide range reported in the literature. For example, Sorensen et al. (1990) reported for net-plankton concentrations of $\mathrm{T}-\mathrm{Hg}$ from $9.50 \mu \mathrm{g} \mathrm{kg}^{-1}$ d.w. to $209 \mu \mathrm{g} \mathrm{kg}^{-1}$ d.w., while Nguyen et al. (2005) calculated for Lake Balaton (Hungary) copepods the mean concentration of $\mathrm{T}-\mathrm{Hg}$ of $0.31 \div 6.8 \mu \mathrm{g}$ $\mathrm{kg}^{-1}$. The variability of the $\mathrm{MeHg}$ concentrations is not lower than that of T-Hg; for example, Wescott \& Kalff (1996) reported concentrations of organic mercury from 19 to $448 \mu \mathrm{g} \mathrm{MeHg} \mathrm{kg}{ }^{-1}$ d.w. and Back \& Watras (1995) concentrations from 1 to $479 \mu \mathrm{g} \mathrm{kg}^{-1}$.

To obtain homogenous zooplankton samples, Watras $\&$ Bloom (1992) were the first to measure the T-Hg and $\mathrm{MeHg}$ concentrations in samples composed of 5 to 20 zooplankters. A very interesting research was performed by Back \& Watras (1995) on the MeHg concentrations in single species of zooplankton from 12 lakes (Wisconsin, USA). The concentrations varied with the species and the environment; for example, the $\mathrm{MeHg}$ concentration in Holopedium gibberum varied from 40 to 479 $\mu \mathrm{g} \mathrm{kg}^{-1}$ d.w. and in Diaptomus minutum and D. oregonensis from 22 to $66 \mu \mathrm{g} \mathrm{kg}^{-1}$. In addition, the $\mathrm{MeHg}$ concentrations in four species of Daphnia (D. pulex, D. galeata, D. mendotae and D. ambigua) varied from 1 to $211 \mu \mathrm{g} \mathrm{kg}^{-1}$.

\subsection{Macrophytes}

Wide interspecific variation in $\mathrm{T}-\mathrm{Hg}$ and $\mathrm{MeHg}$ concentrations was measured for macrophytes (Trapa natans, Myriophyllum spicatum, Nymphoides peltata), all of which presented a low $\mathrm{MeHg}$ concentration in comparison to fish and zooplankton. This might suggest that at least a part of the mercury measured in the macrophytes was not metabolized, but adsorbed on the plant surface. 
In spite of their low mercury concentrations, macrophytes may play an important role in environments in which their biomass is abundant. In this case the total content of mercury in the macrophytes assumes great importance from a biogeochemical point of view.

\subsection{Molluscs}

Since the freshwater mussel Dreissena polymorpha, commonly used as a bioindicator of the environment pollution level (Busch \& Schuchardt 1991; De Kock \& Bowmer 1993; Camusso et al. 2001) has not yet invaded Lake Candia, it seemed interesting to use as a bioindicator for mercury another common freshwater mussel (Unio pictorum mancus), which has been successfully tested for other metals on previous occasions (Beone \& Ravera 2003; Ravera et al. 2003a, 2003b, 2005, 2007a, 2007b). The T-Hg mean concentration in the soft tissues of Unio from Lake Candia, $38 \mu \mathrm{g} \mathrm{kg}^{-1}$ d.w., is of the same order of magnitude as that measured in Dreissena from the largest Northern Italian lakes (Camusso et al. 2001). As an example, the mean concentration of T-Hg in Dreissena ranges from $49 \mu \mathrm{g} \mathrm{kg}^{-1}$ d.w. in Lake Lugano to $53 \mu \mathrm{g} \mathrm{kg}^{-1}$ d.w. in Lake Como and $65 \mu \mathrm{g} \mathrm{kg}^{-1}$ d.w. in Lake Garda and Lake Iseo. The highest concentration $\left(158 \mu \mathrm{g} \mathrm{kg}^{-1}\right.$ d.w.) measured by the same authors, in animals from Lake Maggiore, could be explained by the relatively high pollution level of the sampling site (Pallanza Gulf), which was affected by various industrial effluents during the 1960s and 70s.

The concentration of metal in the mussel tissues is the result of a balance between the tissue growth-rate and the metal accumulation rate. If the tissue growth rate exceeds the accumulation rate, the concentration of mercury decreases with the mussel's size, while the opposite occurs when the mussel grows more slowly than the rate of metal accumulation. Therefore the negative relationship between mercury concentration and mussel size that we observed in the eutrophic Lake Candia could be the result of a dilution effect due to rapid mussel growth enhanced by high food availability (Fig. 3).

To evaluate the potential impact of a population on its environment, the element (in this case mercury) content can be estimated when population density is known. In Lake Candia, for instance, given a mean value of 6.93 individuals $\mathrm{m}^{-2}$ and a mean individual T$\mathrm{Hg}$ content of $0.078 \mu \mathrm{g}$, the total content of $\mathrm{Hg}$ in the mussel tissues is $0.54 \mu \mathrm{g} \mathrm{Hg} \mathrm{m}^{-2}$ (Ravera 2008). This value, which represents the amount of mercury sequestered by the live mussels, and which will be returned to the environment after their death, is commonly neglected in spite of its importance from an ecological point of view.

\subsection{Biomagnification}

Some authors attribute the high mercury concentration measured in large-sized fish to their high longevity, which gives them a sufficiently long time to accumulate a larger amount of mercury than fish species with a shorter life span (e.g., Knauer \& Martin 1972; Williams $\&$ Weiss 1973). Presently there is general agreement about attributing the mercury concentration in different species to their position in the food chain (Cabana \& Rasmussen 1994; Kidd et al. 2003; Hammerschmidt \& Fitzgerald 2006; Orihel et al. 2007; Campbell et al. 2008). The abundant information on this concept, called "biomagnification", demonstrates that mercury concentration increases from the lower (primary producers) to the middle (herbivores) and upper (carnivores) trophic levels. An example is provided by Hammerschmidt \& Fitzgerald (2006), whose study of the $\mathrm{MeHg}$ concentration in an aquatic food chain found the following sequence of increase: filtered water $\left(0.00003 \mathrm{ng} \mathrm{g}^{-1} \mathrm{ww}\right)$ $<$ seston $\left(0.5 \mathrm{ng} \mathrm{g}^{-1} \mathrm{ww}\right)<$ zooplankton $\left(1.1 \mathrm{ng} \mathrm{g}^{-1} \mathrm{ww}\right)$ $<$ fish (27 $\left.\mathrm{ng} \mathrm{g}^{-1} \mathrm{ww}\right)$. Studies on biomagnification contribute to extending knowledge of the trophic structure of a community through the assessment of the distribution of pollutants (such as mercury) in the different taxa. Nevertheless, while it is relatively easy to study linear food chains (e.g., grass-cow-man), more difficulties arise when we are faced with the more complicated food webs which commonly occur in the majority of environments. In fact, most preys are generally preyed upon by different predators, most species are omnivorous and feed on different trophic levels, and seasonal and agedependent shifts in diet are quite common. A significant contribution to solving these problems was made by the use of stable isotopes $\left({ }^{13} \mathrm{C}\right.$ and $\left.{ }^{15} \mathrm{~N}\right)$, which made it possible to investigate the food web in greater detail and to identify the trophic relationships between species (e.g., Fry 1991). For instance, some very detailed studies used this technique to demonstrate mercury biomagnification across the food web of tropical lakes (Campbell et al. 2003a; Kidd et al., 2003; Campbell et al. 2008; Poste et al. 2008).

Since fish is the most important source of $\mathrm{MeHg}$ for man (Fitzgerald \& Clarkson 1991), the studies on food chains ending with fish are also useful from a practical point of view. In fact, if we know the human diet and the mercury concentration in the successive levels of the food chain, the amount of mercury taken up daily by man can be predicted. Even though our data are not sufficient to build up a trophic food chain, we found clear evidence of biomagnification from the lower to the upper trophic levels. There is a clear increase from the 1 st level, represented by macrophytes (mean concentration $=28.9 \mu \mathrm{g} \mathrm{T}-\mathrm{Hg} \mathrm{kg}^{-1} \mathrm{~d}$.w.) to the $2^{\text {nd }}$ level, represented by Unio (37.9 $\mu \mathrm{g} \mathrm{T-Hg} \mathrm{kg}{ }^{-1}$ d.w.) and net-zooplankton $\left(77 \mu \mathrm{g} \mathrm{kg}^{-1}\right)$, and to the $3^{\text {rd }}$ level, represented by young cat-fish (143 $\mu \mathrm{g} \mathrm{kg}^{-1} \mathrm{~d}$.w.). The different concentrations found in Unio and zooplankton are probably due to differences in their diet: while the diet of zooplankton essentially consists of phytoplankton and seston, mussels mainly feed on phytoplankton and 
sediment organic particles. Unfortunately, only $\mathrm{T}-\mathrm{Hg}$ was measured in the cat-fish, but since organic mercury in fish is generally higher than $95 \%$ (e.g., Bloom 1992), we can reasonably assume that the percentage of $\mathrm{MeHg}$ in the cat-fish would be higher than that calculated in other compartments.

\section{CONCLUSIONS}

The level of mercury contamination in Lake Candia is fairly low. The highest value, which was measured in young cat-fish $\left(143 \mu \mathrm{g} \mathrm{kg}^{-1}\right.$ d.w.), is 1.4 times lower than the threshold recommended by W.H.O. (1990; 200 $\mu \mathrm{g} \mathrm{kg}^{-1}$ ) for this fish, which represents the sole source of protein for some populations; for example, fishermen living in some Pacific islands.

Data on environments with a low mercury concentration, such as Lake Candia, can be used to establish a background value which is particularly useful for evaluating the level of pollution in other environments.

Useful indicators of mercury contamination are fish, mussel (Unio pictorum mancus) and net-zooplankton; fish, for their capacity to accumulate mercury in their tissues without any apparent damage, the bivalve for its sedentary behaviour, while the zooplankton's short life span makes it a useful indicator of the daily pollution level. Conversely, macrophytes cannot be recommended as a useful indicator because of their low capacity to accumulate mercury and its organic forms.

To assess the actual importance of mercury accumulation in the various compartments of the ecosystem, the metal content in each compartment, in addition to the metal concentration, should be estimated. This would provide useful information on the dynamics of mercury in the environment and on the relative impact of each community compartment on the metal biogeochemical cycle.

\section{ACKNOWLEDGEMENTS}

The authors are very grateful to reviewers: Dr. L. Guzzi (CESI-Research, Italy), Prof. J.L. Jamet (Université de Toulon-Var, France) and Prof. D. Lajus (St. Petersburg State University, Russia) for their constructive comments. Grateful thanks are due to Mrs Sandra Spence for the careful English revision.

\section{REFERENCES}

Back, R.C. \& C.J. Watras. 1995. Mercury in zooplankton of northern Wisconsin Lakes: Taxonomy and site-specific trends. Water Air Soil Poll., 80: 931-938.

Beone, G.M. \& O. Ravera. 2003. Vantaggi e limiti del monitoraggio ambientale mediante l'analisi chimica dei Lamellibranchi. Studi Trent. Sci.-Nat. Acta Biol., 78(1): 79-84.

Bloom, N.S. 1992. On the chemical form of mercury in edible fish and marine invertebrate tissue. Can. J. Fish. Aquat. Sci., 49: 1010-1017.

Busch, D. \& B. Schuchardt. 1991. The use of the fresh water mussel Dreissena polymorpha, Pallas for biomonitoring heavy metals in limnic ecosystems: the Weser. Ver. Internat. Verein. Limnol., 24: 2261-2264.
Cabana, G. \& J.B. Rasmussen. 1994. Modelling food chain structure and contaminant bioaccumulation using stable nitrogen isotopes. Nature, 372: 255-273.

Campbell, L.M., Hecky, R.E., Nyaundi, J., Muggide, R. \& D.G. Dixon. 2003. Distribution and the food web transfer of mercury in Napoleon and Winam Gulfs, Lake Victoria. East Africa J. Gt. Lakes Res., 29: 267-282.

Campbell, L., P. Verburg, P. D \& R.E. Hecky. 2008. Mercury biomagnification in the food-web of Lake Tanganyika (Tanzania, East Africa). Sci. Total Environ., doi:10.1016/j.scitotent 2008.04.0-17.

Campeau, G. \& R. Bartha. 1984. Methylation and demethylation of mercury under controlled redox, $\mathrm{pH}$ and salinity condition. Appl. Environ. Microbiol., 48: 1203-1207.

Camusso, M.R. Balestrini \& A. Binelli. 2001. Use of zebra mussel (Dreissena polymorpha) to assess trace metal contamination in the largest Italian subalpine lakes. Chemosphere, 44: 263-270.

Cattani, I., Spalla, S., Beone, G.M., Del Re, A.A.M., Boccelli, R. \& M. Trevisan. 2008. Characterization of mercury species in soils by HPLC-ICP-MS and measurement of fraction removed by Diffusive Gradient in Thin film. Talanta, 74: $1520-1526$.

De Kock, W.C. \& C.T. Bowmer. 1993. Bioaccumulation, biological effects and food chain transfer of contaminants in the zebra mussel (Dreissena polymorpha). In: T.F. Nalepa \& D.W. Schloesser (Eds), Zebra mussels: Biology, Impacts and control.C.R.C. Press, Boca Raton (FL) U.S.A.

Fitzgerald, W.F. \& T.W. Clarkson. 1991. Mercury and monomethylmercury: Present and future concerns. Environ. Health Perspect., 96: 159-166.

Fry, B. 1991. Stable isotope diagrams of freshwater food webs. Ecology, 72: 2293-2294.

Gardfeldt, K., J. Munthe, D. Stromberg \& O. Lindquist. 2003. A kinetic study on the abiotic methylation of divalent mercury in the aqueous phase. Sci. of the Total Environ., 303: $127-136$.

Giussani, G. \& G. Galanti. 1992. Experience in eutrophication recovery by biomanipulation. In: P. Guilizzoni, G. Tartari and G. Giussani (Eds), Limnology in Italy. Mem. Ist. ital. Idrobiol., 50: 397-416.

Grieb, T.M., C.T. Driscoll, S.P. Gloss, C.L. Schofield, G.L. Borrie \& D.B. Porcella. 1990. Factors affecting mercury accumulation in fish in the upper Michigan peninsula. Environmental Toxicology and Chemistry, 9: 919-930.

Hall, B.D., R.A. Bodaly, R.G.P. Fudge, J.W.M. Rudd \& D.M. Rosenberg. 1997. Food as the dominant pathway of methylmercury uptake by fish. Water Air Soil Pollut., 100: 13-24.

Hammerschmidt, C.R. \& W.F. Fitzgerald. 2006. Bioaccumulation and trophic transfer of methylmercury in Long Island Sound. Arch. Environ. Contam. Toxicol., 51: 416-424.

Hintelmann, H. \& R.D. Evans. 1997. Application of stable isotopes in environmental tracer studies: measurements of monomethylmercury $\left(\mathrm{CH}_{3} \mathrm{Hg}^{+}\right)$by isotope dilution ICPMS and detection of species transformation. Fresenius $J$. Analyt. Chem., 358: 378-385.

Kidd, K.A., H.A. Bootsma, R.H. Hesslein, L. Lockhart \& R.E. Hecky. 2003. Mercury concentrations in the food-web of Lake Malawi, East Africa. J. Great Lakes Res., 29 (Suppl. 2): 258-266.

Knauer, G.A. \& J.H. Martin. 1972. Mercury in a pelagic food chain. Limnol. Oceanogr., 17: 868-876.

Jensen, S. \& A. Jernelöv. 1969. Biological methylation of mercury in aquatic organisms. Nature, London, 220: 753-754.

Jernelov, A. \& H. Lann. 1971. Mercury accumulation in food chains. Oikos, 22: 403-406.

Mason, R.P., J.R. Reinfelder \& F.M.M. Morel. 1996. Uptake, toxicity and trophic transfer of mercury in a coastal diatom. Environ. Sci. Technol., 30: 1835-1845. 
Nguyen, H.L., M. Leemakers, S. Kurunczi, L. Bozo \& W. Baeyens. 2005. Mercury distribution and speciation in Lake Balaton, Hungary. Sci. Total Environ., 140: 231-246.

Orihel, D.M., M.J. Paterson, P.J. Blanchfield, R.A. Bodaly \& H. Hintelmann. 2007. Experimental evidence of a linear relationship between inorganic mercury loading and methylmercury accumulation by aquatic biota. Environ. Sci. Technol., 41: 4952-4958.

Poste, A.E., Hecky, R.E. \& D. Muir, 2008. Biomagnification of mercury in a West African crater lake (Lake Bosomtwe, Ghana). Ver. Internat. Verein. Limnol., 30: 647-650.

Rambal, P.S., J.W.M. Rudd \& R.E. Hecky. 1986. Methods for measuring specific rates of mercury methylation and degradation and their use in determining factors controlling net rates of mercury methylation. Applied and Environm. Microbiol., 51: 110-114.

Ravera, O. 2008.An index for estimating the potential impact on the environment of the pollutant content in aquatic populations. J. Limnol., 67(1): 70-74.

Ravera, O., R. Cenci, G.M. Beone, M. Dantas \& P. Lodigiani. 2003a. Trace element concentrations in freshwater mussels and macrophytes as related to those in their environment. J. Limnol., 62(1): 61-70.

Ravera, O., G.M. Beone, R. Cenci \& P. Lodigiani. 2003b. Metal concentrations in Unio pictorum mancus (Mollusca, Lamellibranchia) from 12 Northern Italian lakes in relation to their trophic level. J. Limnol., 62(2): 121-138.

Ravera, O., P.R. Trincherini, G.M. Beone \& B. Maiolini. 2005. The trend from 1934 to 2001 of metal concentrations in bivalve shells (Unio pictorum) from two small lakes: Lake Levico and Lake Caldonazzo (Trento Province, Northern Italy). J. Limnol., 64(2): 113-118.

Ravera, O., A. Frediani \& N. Riccardi. 2007a. Seasonal variations in population dynamics and biomass of two Unio pictorum mancus (Mollusca, Unionidae) populations from two lakes of different trophic state. J. Limnol., 66(1): 15-27.

Ravera, O., G.M. Beone, P.R. Trincherini \& N. Riccardi. 2007b. Seasonal variations in metal content of two Unio pictorum mancus (Mollusca, Unionidae) populations from two lakes of different trophic state. J. Limnol., 66(1): 28-39.

Sorensen, J.A., G.E. Glass, K.W. Schmidt, J.K. Huber \& G.R. Rapp Jr. 1990. Airborne mercury deposition and watershed characteristics in relation to mercury concentrations in water, sediment, plankton and fish of eighty Northern Minnesota lakes. Environ. Sci. Technol., 24: 1716-1727.

Tsui, M.T.K. \& W.X. Wang. 2004. Uptake and elimination routes of inorganic mercury and methylmercury in Daphnia magna. Environ. Sci., 38: 808-816.

Ulbrich, S.M., M.A. Ilyuschchenko, T.W. Tanton and G.A. Uskov. 2007. Mercury contamination in the vicinity of a derelict chlor-alkali plant. Par II: Contamination of the aquatic and terrestrial food chain and potential risks to the local population. Sci. Total Environ., doi: 10.1016/j.scitotenv 2007.02.020.

Watras, C.J. \& N.S. Bloom. 1992. Mercury and methylmercury in individual zooplankton: implications for bioaccumulation. Limnol. Oceanogr., 37: 1313-1318.

Westcott, K. \& J. Kalff. 1996. Environmental factors effecting methyl mercury accumulation in zooplankton. Can. J. Fish. Aquat. Sci., 53: 2221-2228.

W.H.O. IPCS 1990. Environmental Health Criteria Methylmerucy. Geneva, Switzerland: International Programme of Chemical Safety. W.H.O. 1990.

Williams, P.M. \& H.V. Weiss. 1973. Mercury in the marine environment: Concentration in sea water and in a pelagic food chain. J. Fish. Res. Bd. Can., 30: 293-295.

Received: February 2009

Accepted: June 2009 